\title{
Status of Centralized Environmental Creep Testing Facility Preparation and Upgrade
}

Weiju Ren and Richard Battiste

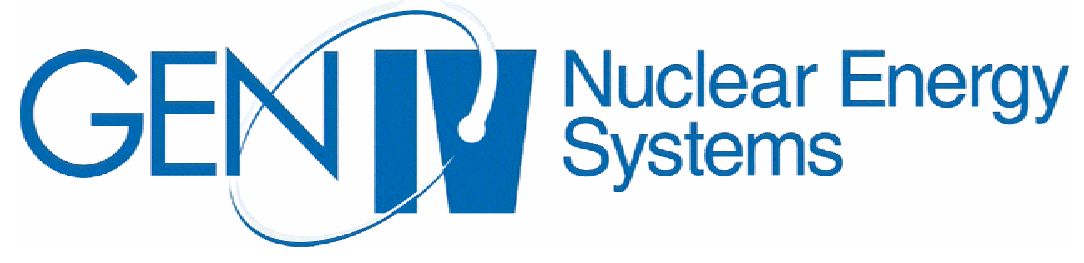

September 12, 2006

\section{UT-BATTELLE}

OMK RIDGE NATZONAL LABORNTORY 
This report was prepared as an account of work sponsored by an agency of the United States Government. Neither the United States government nor any agency thereof, nor any of their employees, makes any warranty, express or implied, or assumes any legal liability or responsibility for the accuracy, completeness, or usefulness of any information, apparatus, product, or process disclosed, or represents that its use would not infringe privately owned rights. Reference herein to any specific commercial product, process, or service by trade name, trademark, manufacturer, or otherwise, does not necessarily constitute or imply its endorsement, recommendation, or favoring by the United States Government or any agency thereof. The views and opinions of authors expressed herein do not necessarily state or reflect those of the United States Government or any agency thereof. 


\title{
Status of Centralized Environmental Creep \\ Testing Facility Preparation and Upgrade
}

\author{
Weiju Ren and Richard Battiste
}

September 12, 2006

Prepared for

Office of Nuclear Energy

Prepared by

OAK RIDGE NATIONAL LABORATORY

Oak Ridge, Tennessee 37831

managed by

UT-BATTELLE, LLC

for the

U.S. DEPARTMENT OF ENERGY

Under DOE Contract No. DE-AC05-00OR22725 


\begin{abstract}
ABTRACT
Because the ASME Codes do not cover environmental issues that are crucial in the design and construction of VHTR system, investigation of long-term impure helium effects on metallurgical stability and properties becomes very important. The present report describes the development of centralized environmental creep testing facility, its close collaborations with the experiments in low velocity helium recirculation loop, important lessons learned, upgrades in system design in FY06, and current status of the development.
\end{abstract}




\section{CONTENTS}

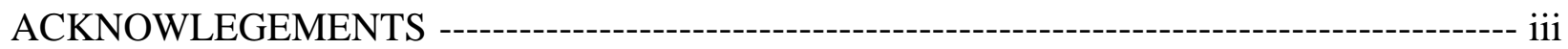

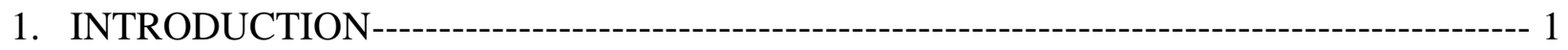

2. SYSTEM DESIGN AND UPGRADE CONSIDERATIONS ----------------------------------- 3

2.1 Initial Design Considerations and Activities ---o---o- 3

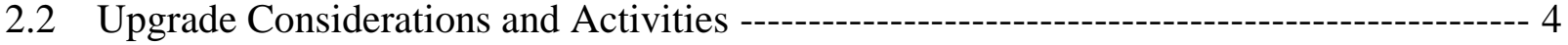

3. CURRENT STATUS AND CONSIDERATIONS

FOR FUTRE DEVELOPMENT ----13

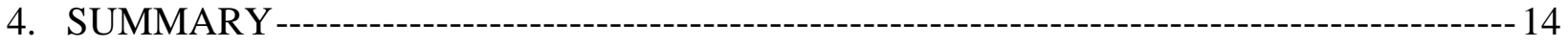

5. REFERENCES ----15

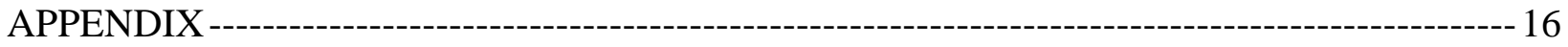




\section{ACKNOWLEDEMENTS}

The authors are grateful to William Corwin for programmatic direction and constructive comments; to Dane Wilson, Lynn D. Chitwood and Adam Willoughby for advice in environmental creep system design and upgrade, to Scott Bell for technical support.

This work is sponsored by the U.S. Department of Energy, Office of Nuclear Energy Science and Technology under contract DE-AC05-00OR22725 with Oak Ridge National Laboratory, managed by UT-Battelle, LLC. 


\section{INTRODUCTION}

In the development of the Gen IV nuclear reactor systems, the leading candidate reactor concept, dubbed as the Very High Temperature Reactor (VHTR), is a helium-cooled, graphitemoderated, thermal neutron spectrum reactor with a target outlet temperature of $950^{\circ} \mathrm{C}\left(1742^{\circ} \mathrm{F}\right)$. Ninety percent of the high temperature helium output from the VHTR will be directed to a helium gas turbine with or without an intermediate heat exchanger (IHX) for electricity generation, and the remaining ten percent will be coupled through an IHX with heat application processes for hydrogen production. The design service life of the VHTR system is targeted for 60 years. During the long-term services, many of the VHTR components will be operating in a helium environment under stress at very high temperatures.

Because the thermal, environmental, and service life conditions required for the VHTR concept are unprecedented for the design of many of the high temperature components in the reactor system, down-selection and qualification of the candidate structural materials face significant challenges. Three major challenges include the effects of helium contaminants, high temperature exposure, and long-term irradiation, on microstructure stability and mechanical properties. Although all the structural materials for Gen IV nuclear reactor construction must be qualified by American Society of Mechanical Engineers (ASME) Codes and Standards, it should be realized that the ASME Codes and Standards do not address impure helium or irradiation effects on long-term microstructural stability and mechanical properties. In reality, it is impractical and extremely expensive, if not completely impossible, to maintain high purity of the large quantities of coolant helium that are circulating in the VHTR during decades of operation. Impurities can be generated from outgassing of the reactor graphite and thermal insulation materials; corrosion of metallic components; radiolytic reactions; and air, water and hydrocarbon ingress from various sources [1 - 2]. Since the contamination is inevitable, some impurities may be intentionally added for desired chemical reaction control purposes. The helium contaminants may include impurities such as $\mathrm{N}, \mathrm{CO}, \mathrm{CO}_{2}, \mathrm{H}_{2}, \mathrm{H}_{2} \mathrm{O}$, and $\mathrm{CH}_{4}$. Controlling the concentration of these impurities can be a very complicated process. According to the experiences from other existing reactors, a dynamic equilibrium usually occurs between the rate of impurity supply and the rate of impurity removal, by the gas purification system and reactions in the reactor core [3]. Even with the contaminant concentrations well controlled, the impure helium may still cause undesirable chemical reactions on the surfaces of the reactor component structural materials, resulting in environmental degradation mechanisms such as oxidation, carburization, or decarburization that alters mechanical properties of the materials. Over the long reactor service life, accumulation of mechanical properties deterioration could eventually lead to components failure, and serious accidents could follow.

To ensure confidence in materials selection for Gen IV nuclear reactor design and construction, information on impure helium effects must be acquired; and the degradation of mechanical properties resulting from the impure helium exposure must be measured in a quantitative manner. The measurements may be used to qualify or disqualify a candidate material, or be incorporated into safety or knock-down factors for design considerations. To generate such information, candidate materials must be tested in various simulated VHTR service conditions. For this purpose, low and/or high velocity helium recirculation loops have been developed at the Oak Ridge National Laboratory (ORNL) and the Idaho National 
Laboratory (INL) to expose candidate materials in impure helium environment for testing and characterization. However, the simulations in these loops are used mostly to investigate the chemical reaction aspect of the VHTR operating environment, with little consideration of stress effects. In the VHTR applications, the component materials will be serving in impure helium environment under various operation loads. Possible synergism of helium contaminants and stresses could occur, and the result could be accelerated deterioration processes.

To more closely simulate the VHTR operating conditions and investigate the effects of possible synergism of impure helium and stress on long-term metallurgical stability and mechanical properties of the candidate materials, environmental creep testing must be conducted. The candidate materials must be tested under various stresses at very high temperatures in impure helium gas. To properly design the testing, the impure helium composition must be well controlled based on the information, knowledge, and experience gained from the on-going development of the low velocity helium recirculation loop experiments. Meanwhile, the stresses and temperatures must be selected based on the information, knowledge, and experience from the baseline creep testing that provide the data for ASME Codes and Standards qualification in air environment.

It should be noted that the environmental creep testing is intended not only to provide creep properties data in the impure helium environment to compare with the baseline creep properties data from the air environment, but also to generate crept and impure-helium-exposed specimens for tensile testing to investigate the effects of creep in impure helium on short-term tensile properties. The investigation will provide understanding of the candidate materials' response to sudden load transients after long-term services under the VHTR operating conditions. Depending on the data needs, very low frequency environmental creep-fatigue data can also be generated from the environmental creep testing facility. Furthermore, the environmental creep testing will provide tested specimens for metallurgical studies. Such studies are needed for understanding microstructural evolution during the material service in the VHTR operating conditions, and thus providing crucial information for life prediction, possible component replacement scheduling, and accident prevention.

To conduct creep testing in impure helium environment, a series of activities has been planned and carried out to develop a centralized environmental creep testing facility. The activities include evaluating the data generation and testing requirements; reviewing and drawing experiences from previous environmental creep facilities; designing a tentative centralized environmental creep testing system; acquiring new information, knowledge, and experience from the on-going low velocity helium recirculation loop development at the Corrosion Group of ORNL; upgrading the tentative system design; designing, specifying, and procuring components for the upgraded system design; installing, testing, and evaluating the system; and designing and preparing specimens for data generation. The present report describes the progress and current status of these activities. 


\section{SYSTEM DESIGN AND UPGRADE CONSIDERATIONS}

\subsection{Initial Design Considerations and Activities}

Activities in the environmental creep testing facility development were initiated in FY05, and the preliminary accomplishments were summarized in a report submitted to the Department of Energy (DOE) in August 2005 [4]. In FY05, the scale of the previous impure helium testing facilities established at both ORNL and the General Electric Company (GE) for the High Temperature Gas-Cool Reactors (HTGR) Program in the late 1970's and early 1980's were reviewed to provide a reference for the current development. The review indicated that the combined creep testing capability at ORNL and GE for the HTGR Program could offer simultaneous testing of up to 415 specimens in simulated HTGR helium environment. Major problems of both the ORNL and GE facilities for the HTGR Program and technologies available today for a much improved testing system development were also analyzed and considered. The analyses and considerations were mainly focused on the detailed designs of the environmental chamber, the loading train, and the data acquisition system. Major components including environmental retorts and furnaces, gas chromatograph (GC), contamination resistant TZM averaging extensometers, speed adjustable weight elevator etc. were ordered by the end of FY05. The initial design of the overall centralized impure helium flow control system, as shown in Fig. 1 , was tentative, awaiting the new information, knowledge, and experience from the on-going development of the low velocity helium recirculation loop at the Corrosion Group.

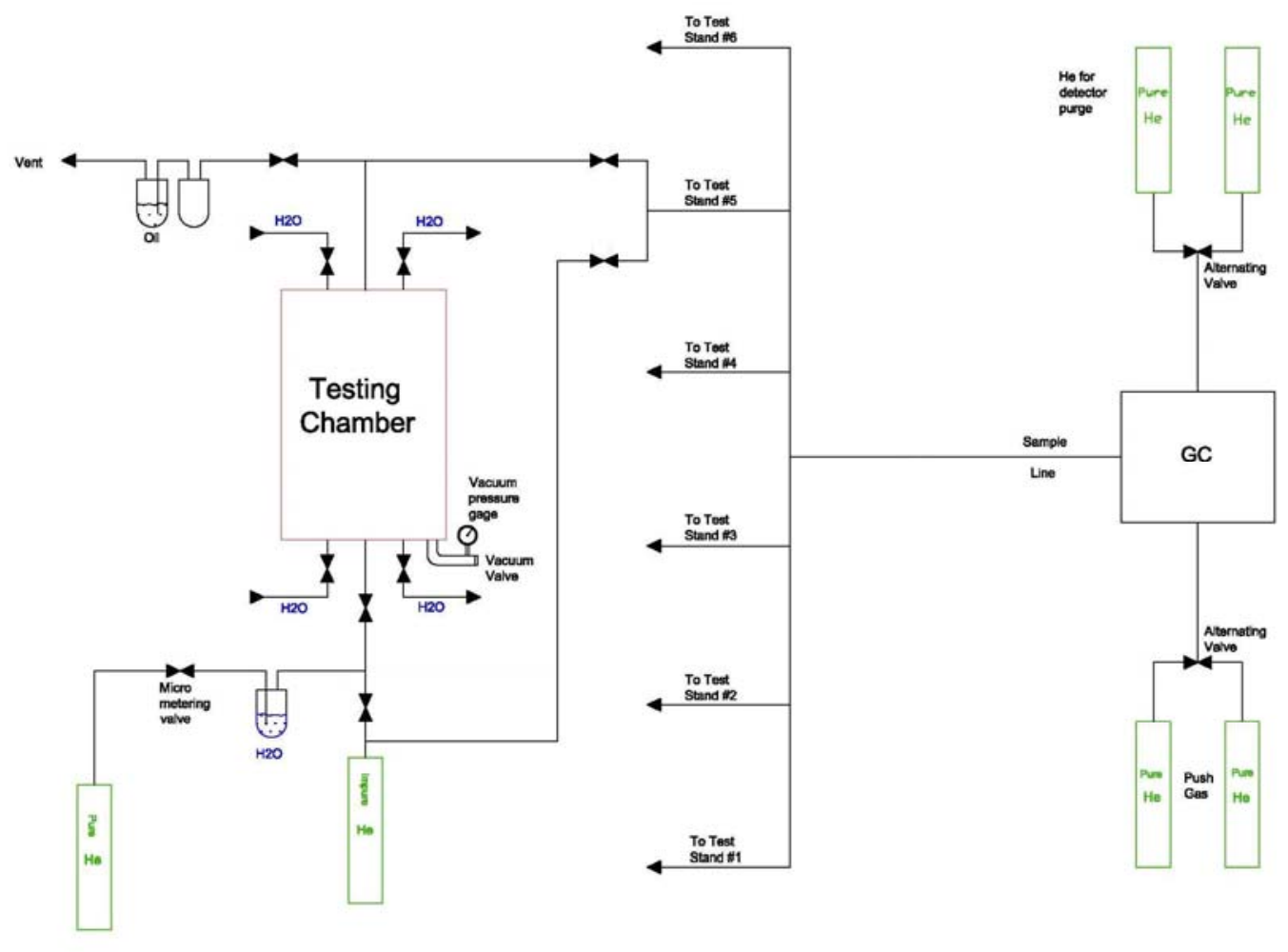

Fig. 1: Initial tentative design for the centralized environmental creep testing system 
In FY05, environmental creep data needs for the Gen IV Program were also analyzed based on the collected existing data under the Gen IV Material Handbook Task summarized in a report submitted to DOE in June 2005 [5]. The collected data indicated that certain amount of creep data generated in the specified HTGR impure helium environment (not the Gen IV VHTR impure helium environment) were available for standard Alloy 617. However, all the original creep curves that are needed for constitutive modeling development were not retrievable. Further, no data in impure helium were generated for Alloy 230. The centralized environmental creep testing facility developed under the present task will be used to fill the existing data gaps for Alloy 617 and produce minimum creep curves required for its model development; and provide all the impure helium environmental creep data for Alloy 230.

\subsection{Upgrade Considerations and Activities}

Although the detailed designs and specifications of major components, such as the environmental chamber, the loading train, the data acquisition system, the gas chromatograph, the contamination resistant TZM averaging extensometers, and the speed adjustable weight elevator etc., were completed in FY05 and remain unchanged in FY06, several significant design upgrades have been conducted on the overall centralized impure helium control system in FY06 as new knowledge and experience from the low velocity helium recirculation loop are developed.

One important piece of information obtained from the development of the low velocity helium recirculation loop is the specification of the impure helium composition. In the absence of designed system data with associated projected leakage rates, specifying the impure helium concentration has been a difficult and time consuming process. A composition as shown in Table 1 was first suggested based on the evaluation of some previously known reactor environments and the factors that contributed to these environments. Then the composition was tried out for verification in the low velocity helium recirculation loop. Stability of the composition at various testing temperatures was tested. Various approaches for attaining the specified composition including adjusting flow rates, blending chambers, materials of construction of test chambers and gas line components, and type and number of purification stations were considered and/or experimented with. The system and component designs were also evaluated for maintaining the composition. A lot of lessons were learned in this process.

Table 1: Impure helium composition suggested for VHTR environmental testing ( $\mu$ atm)

\begin{tabular}{|c|c|c|c|c|c|c|}
\hline Element & $\mathbf{H}_{\mathbf{2}}$ & $\mathbf{H}_{\mathbf{2}} \mathbf{O}$ & $\mathbf{C O}$ & $\mathbf{C O}_{\mathbf{2}}$ & $\mathbf{C H}_{\mathbf{4}}$ & $\mathbf{N}_{\mathbf{2}}$ \\
\hline Maximum & 500 & 3 & 50 & 0.35 & 25 & $<10$ \\
\hline Minimum & 300 & 1 & 30 & 0.05 & 15 & - \\
\hline
\end{tabular}

It became clear from the low velocity helium recirculation loop experience that much more restrictive controls must be implemented in the system to guarantee the required low nitrogen level listed in Table 1. Because nitrogen is the dominant component in air, it can easily get into the loop and exceed the $10 \mu \mathrm{atm}$ level whenever a tiny opening appears. In a large centralized environmental testing system, many operational procedures, such as changing a gas bottle, loading a specimen etc., can cause an opening in the system. Once the nitrogen is in, it takes tremendous efforts to clear it out to reach the required low level in the loop. Besides the 
necessary operational procedures that can create openings in the system, some other factors were also found to lead to nitrogen penetration. After a lot of detective work, certain types of valves and fittings normally used for gas line construction were identified as culprits for nitrogen not reaching the specified low level in the loop. It was speculated that compression fittings with two seal connections were causing the problem. They were all replaced by flare or VCR fittings. Welded Fitting was considered the best from leakage prevention viewpoint but installation and replacement would be very inconvenient. It was also concluded that all the dead corners and ends in the gas line system, most likely exist at $\mathrm{T}$ joints and extended $\mathrm{L}$ turns that can not be flushed by the purge gas, must be eliminated to exclude the possibility of stagnant air.

Armed with the intelligence and lessons learned from the low velocity helium recirculation loop development, a significant design upgrade was carried out to ensure that the specified impurity concentrations will be strictly controlled. In this effort, the initial tentative system shown in Fig. 1 was significantly modified to an upgraded design as presented in Fig. 2. Compared to the initial design in Fig. 1, the upgraded design in Fig. 2 is equipped with a blockand-bleed valve on every gas bottle for clearing air out of the system each time the gas bottle has been changed. In addition to the block-and-bleed valves, many other valves and gas lines were added and sophisticated operation procedures were developed to facilitate gas line cleaning and gas chemistry controlling. To adjust the humidity of impure helium gas, a water filling valve was added to the inlet gas line of each testing chamber, while the outlet branch gas lines with moisture detectors were added to the retort inlet and outlet gas lines, respectively. Another significant design upgrade in Fig. 2 is the addition of the gas calibration subsystem composed of three bottles of certified calibration gas. For long-term testing, the settings of the gas chromatograph may drift, and calibration without breaking the system gas lines and interrupting the on-going tests will be desirable. The calibration subsystem is therefore upgraded as a built-in component for the entire system. Fig. 2 presents one of the important upgrades of the system. To help readers review the functions of various parts in Fig. 2 and understand the needs and scope of the system upgrades, the operational procedures developed for the Fig. 2 version of upgrade is attached in the Appendix.

It should be noted that the design in Fig. 2 is a once-through system. To operate the system, premixed impure helium gas should be custom ordered directly from vendor in bottles and used for the environmental creep testing. The impure helium gas would run through the environmental chamber and exit the system through the outlet vents. The once-through system was initially considered in the design because its structure was simple and the construction would be economical. However, it transpired later in the low velocity helium recirculation loop development that the VHTR impure helium had to be specified in a non-equilibrium state, and its composition would vary as the gas flew through different temperature zones of the system and reacted with the specimen and the internal surfaces of the gas lines. To ensure the impure helium composition around the specimen was as specified, a high gas flow rate had to be maintained to limit the gas residence time in the retort hot zone and reduce impurity depletion. The low velocity helium recirculation loop experiments suggested that the typical flow rates should be between 6 and 15 liters/min. Based on this information, it became obvious that for a oncethrough system, even a very small fraction of those flow rates would be prohibitively expensive to operate. Therefore, a design upgrade to recirculation system was considered. A recirculation 
system would recycle the helium gas and maintain the specified gas chemistry by injecting impurities into the recirculating gas flow.

Several other factors also showed support to the design upgrade to a recirculation system. First, there is experimental proof of viability. Experience from the low velocity helium recirculation loop development and the previous work for HTGR Program at GE proved that a specified impure helium gas composition could be stably achieved in the recirculation system [6]. Second, to maintain constant gas chemistry around the specimen, it was required that only $10 \%$ of any one impurity be consumed after the impure helium passed through the environmental chamber. Conceptually, the recirculation system would provide more confidence that this requirement was met by increasing the gas flow rate to reduce the gas residence time and thus minimize impurity depletion. Third, the once-through system required the purchase of premixed impure helium bottles. It would be very difficult, if not impossible; to compensate for the gas chemistry if adjustments were found necessary in the premixed non-equilibrium gas. Forth, since the recirculation system would recycle its helium gas, the impure helium could be produced by adding the impurities into pure helium gas. The gas supply cylinders could then be located relatively remotely, thus the logistics of installation would be simpler. The fifth reason was a consideration of long-term economy. The high gas flow rates suggested by the development of the low velocity helium recirculation loop completely changed the economic balance between once-through and recirculation systems. The cost for certified pure gases would be less than $\$ 300$ a bottle, while the cost for the certified premixed gas would be approximately $\$ 1400$ a bottle. The high flow rates will make a significant difference because a 580 size bottle would last an estimated 400 hours with a $200 \mathrm{ml} / \mathrm{min}$ leak to vent rate. So, the cost savings in gas in a recirculation system would be approximately $\$ 11,000$ on a 4000 hour tests. Sixth, the recirculation system would provide the capability of running different gas mixtures at each creep machine.

Although the disadvantage of the recirculation system was an increase in loop complexity and initial cost (which was tried to be avoided in the initial once-though system design), with the change of balance between the advantages and disadvantages due to the required high gas flow rates, it was decided that the system should be upgraded to a recirculation design. Fig. 3 shows a schematic of the upgraded design for the present construction. Due to the large size of the original drawing, the details are presented in Fig. 3a - Fig. 3c. A comparison of Fig. 3 with Fig. 2 shows the increase in hardware components. A diaphragm pump, impurity injection sub-loops and a two-bank helium supply system of six bottles each were added. 


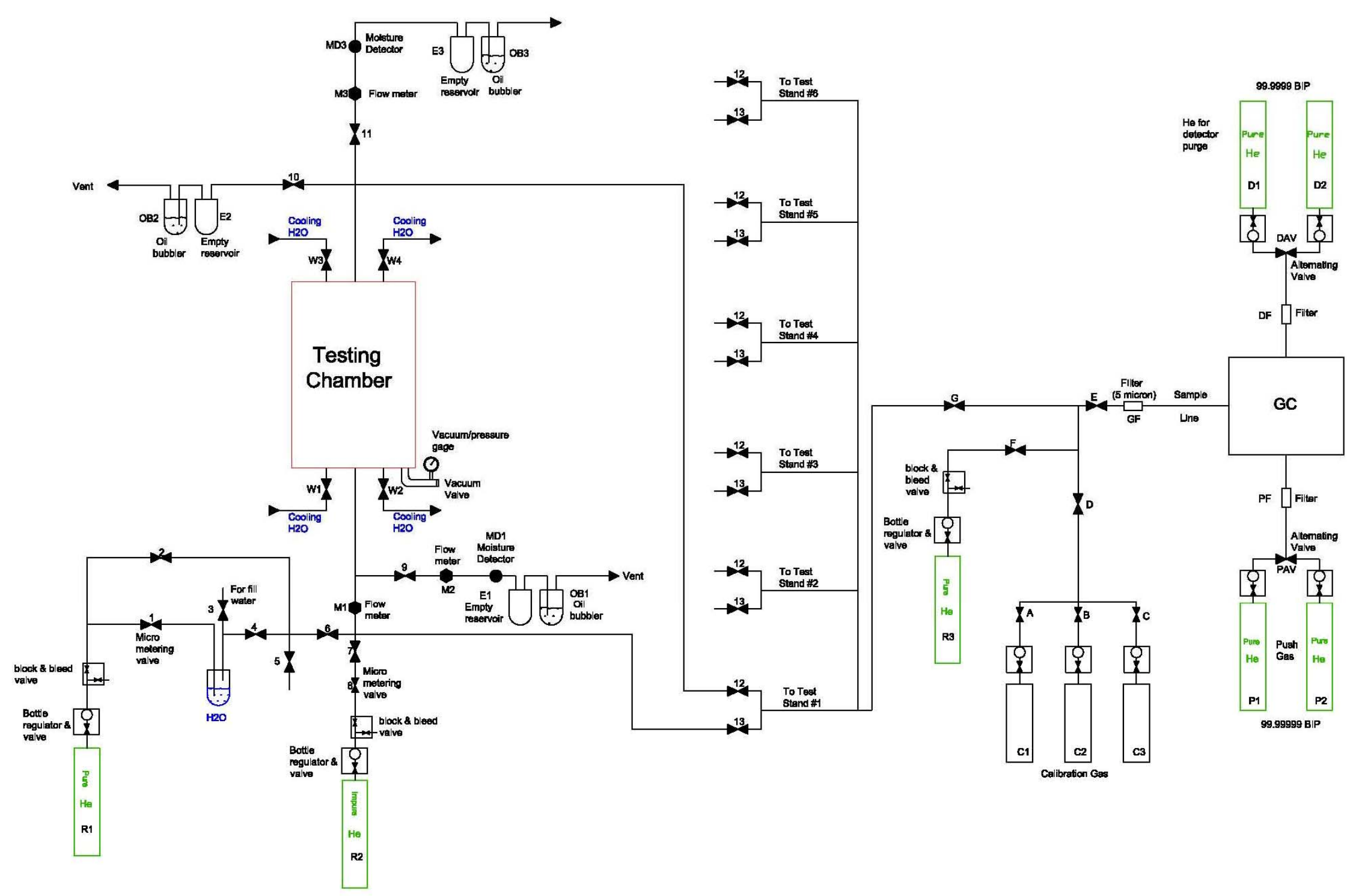

Fig. 2: An upgraded design for the centralized environmental creep testing system 
STATUS OF CENTRALIZED ENVIRONMENTAL CREEP TESTING FACILITY PREPARATION AND UPGRADE

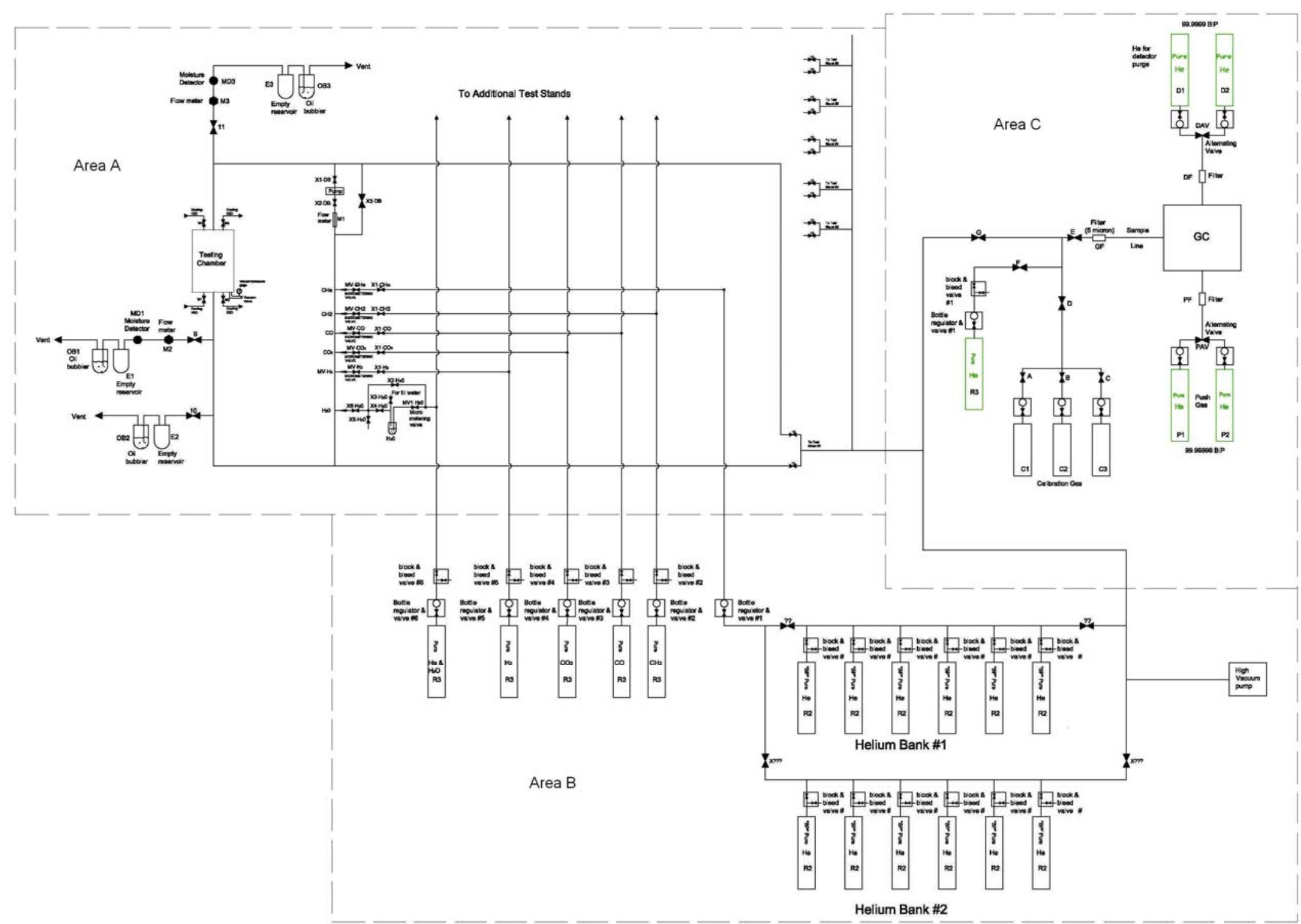

Fig. 3: The present design for the centralized environmental creep testing system 


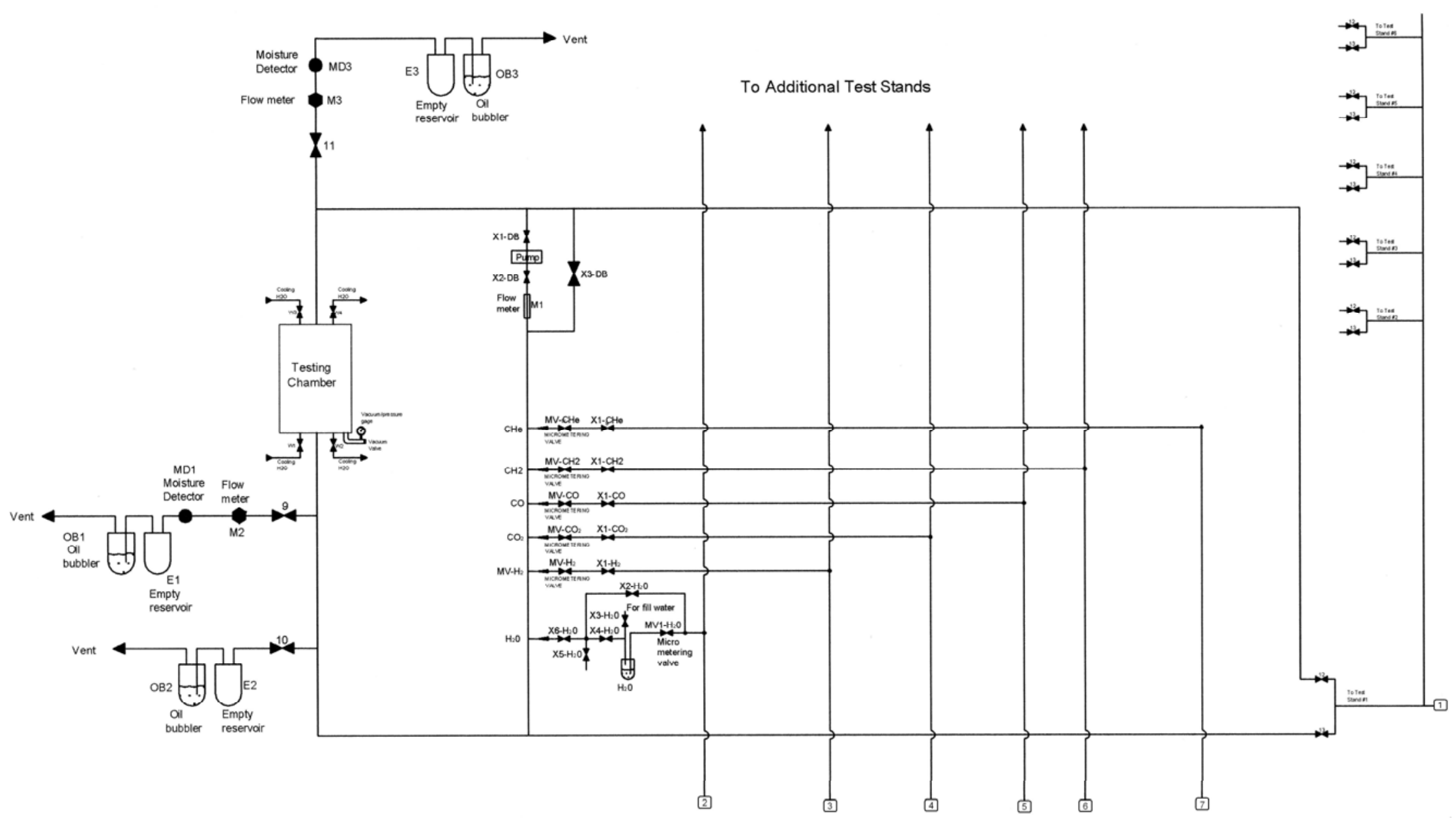

Fig. 3a: Area A of the present design for the centralized environmental creep testing system 


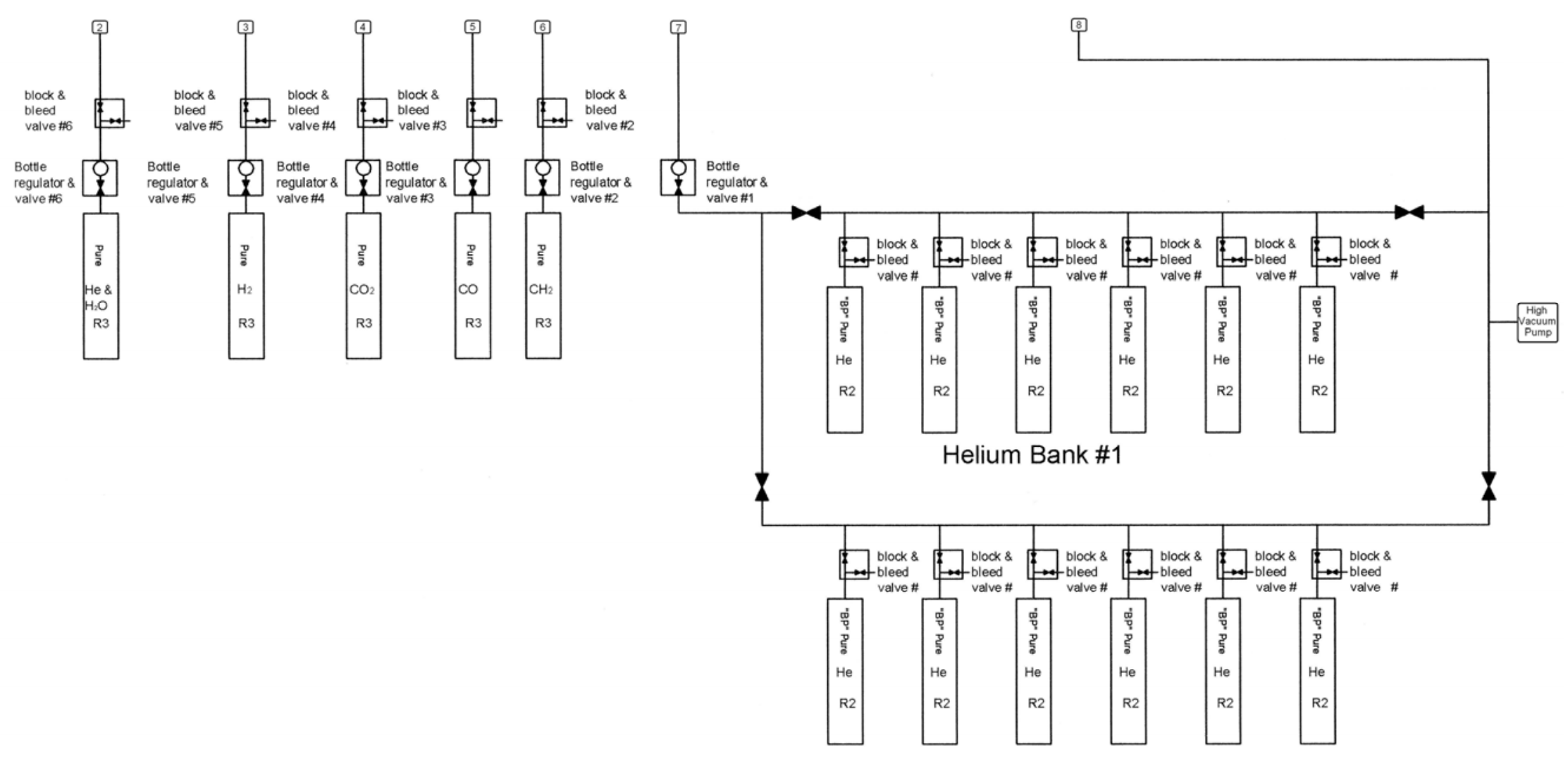

Helium Bank \#2

Fig. 3b: Area B of the present design for the centralized environmental creep testing system 


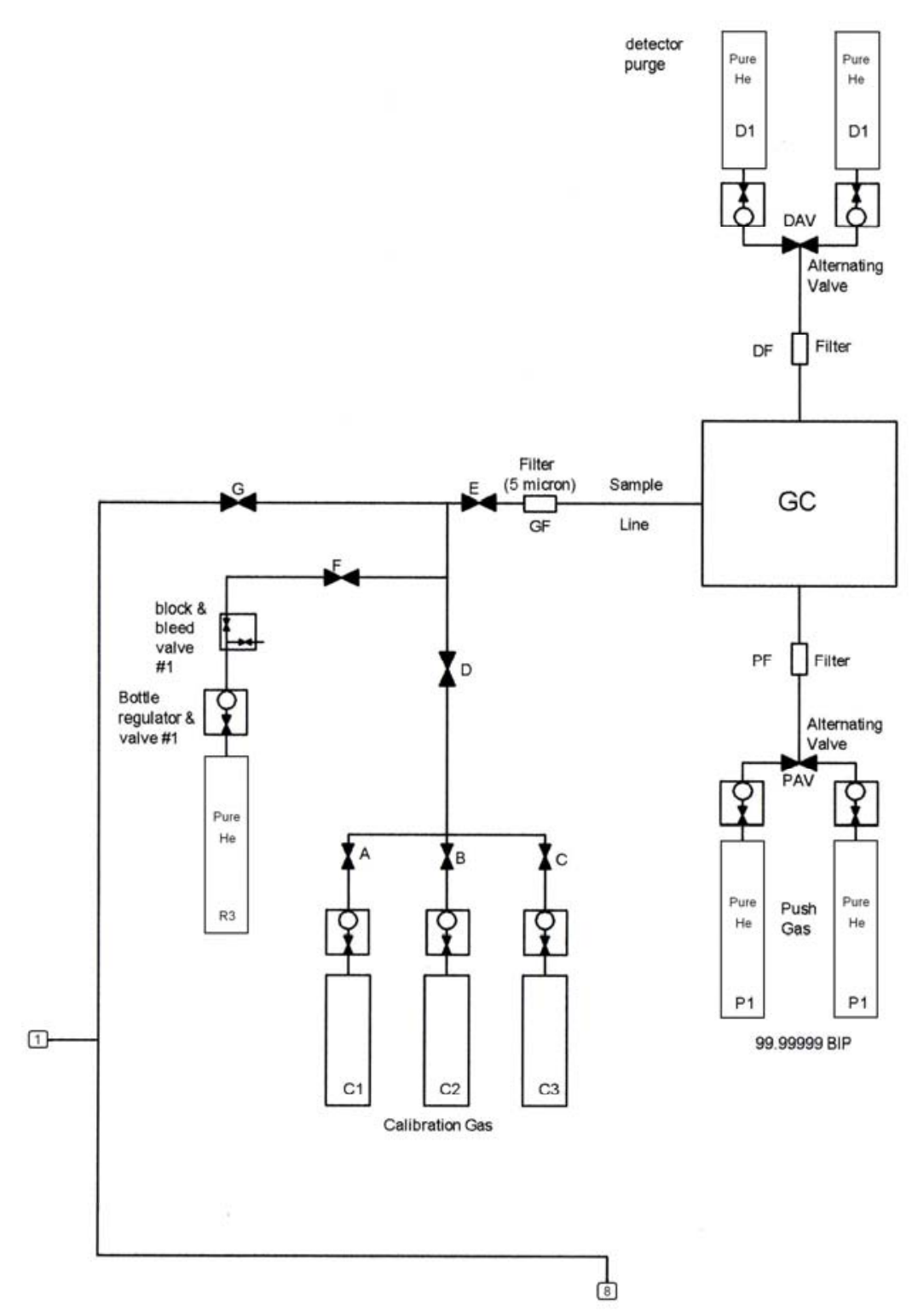

Fig. 3c: Area $\mathrm{C}$ of the present design for the centralized environmental creep testing system 


\section{CURRENT STATUS AND CONSIDERATIONS FOR FUTRE DEVELOPMENT}

Unless there are great new surprises coming out of the low velocity helium recirculation loop development, enough lessons have already been learned to upgrade the design of the centralized environmental creep testing system in FY06, and the current design are considered relatively mature. With the design upgrading needs constantly emerging, construction of the system has been intermittently conducted throughout FY06. When new information became available that might require a significant system design revision, the construction was paused to avoided possible mistakes and waste of labor. In addition, the long lead times for several large custom orders of components also contributed to the intermittent construction. As previously mentioned, orders of all the major components were placed by the end of FY05, and the construction was initiated and continued as the needed parts became available. However, due to the complicity of the system that involved customized components from a wide range of industries, deliveries of those components were spread over many months. The last item ordered by the end of FY05 was not received until end of June 2006.

At present, the construction is underway as the components ordered for the upgrades are continuously being delivered from vendors. Two environmental creep testing chambers with three zone furnace have been installed as shown in Fig. 4. Control cabinet and panel for the furnaces are also assembled. Data acquisition system has been configured, wired, and a first cut at the LabView program complied and verified. Vacuum pump and speed adjustable elevator shown in Fig. 5 have been tested. Gas lines have been partially installed. All the other major components for the two environmental creep testing chambers and the gas chromatograph have also been received except the hydrometers for both chambers and two micro-metering valves for the second chamber. The hydrometers were intentionally not ordered until the identical type was installed and evaluated in the low velocity helium recirculation loop development. The engineering and documentation for a close gas cabinet for the hydrogen, carbon monoxide and methane bottles is near completion and installation can proceed once it is finished. The threebottle cabinet is on site, so there should be no delay on installation. Installation of the gas chromatograph and one machine should be finished by September 30. It should be noted that a high vacuum pump and circuit have been added in an attempt to prevent the introduction of contaminants (mainly nitrogen) when bottles are exchanged. If successful, test durations will be extended beyond the 3000 hour range. As soon as the valves, gas bottles and other needed components for the upgrade are received, the gas lines will be finished to connect all the components into a closed system for testing.

It should be pointed out that because of the very restrictive requirements raised in FY06 for the impure helium composition control, the design has been upgraded to a level that meets the standard for a vacuum system. The elevated standard has increased the cost accordingly. However, because the detailed design of the environmental chamber, the loading train, the data acquisition system, the gas chromatograph, the contamination resistant TZM averaging extensometers, and the speed adjustable weight elevator have remained unchanged, the increased cost is largely a one-time expense for the overall system construction. Once the centralized system is established, the cost for each additional environmental creep testing chamber will essentially remain similar. 


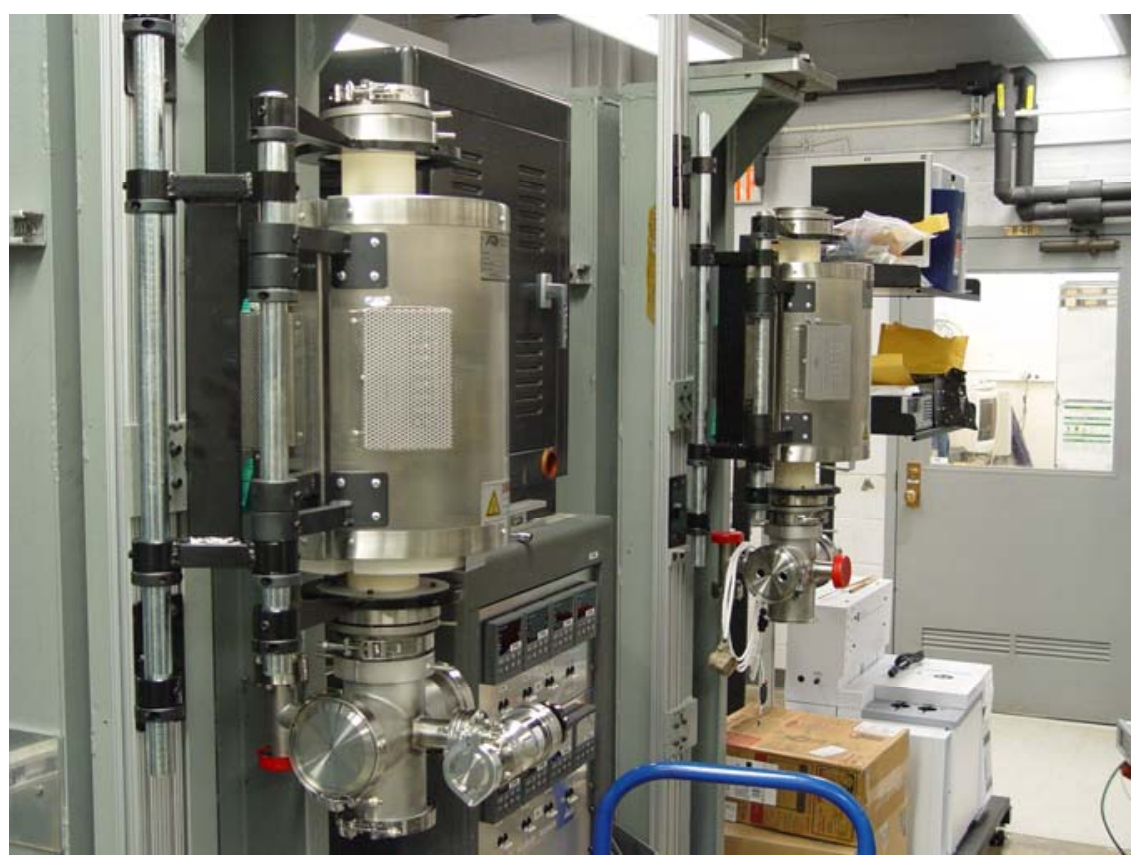

Fig. 4: Installed environmental chamber and control cabinet and panel

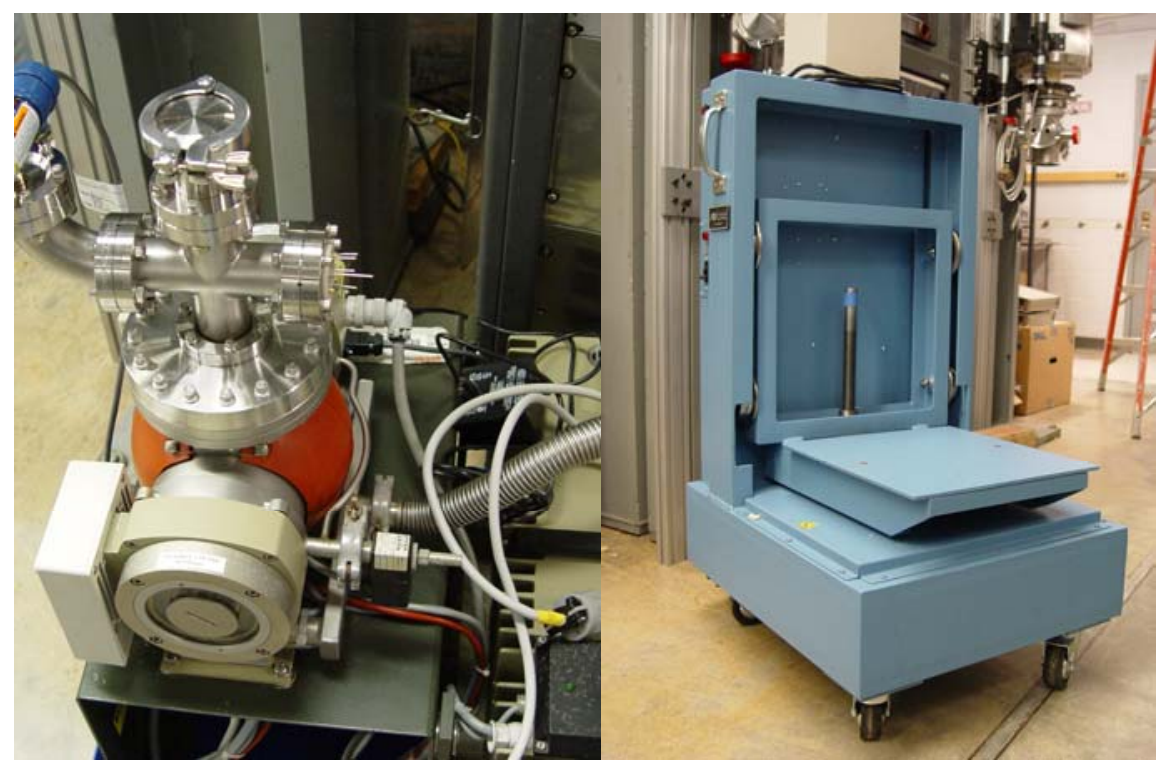

Fig. 5: Vacuum pump and speed adjustable elevator for environmental creep testing operations 


\section{SUMMARY}

In the development of the centralized environmental creep testing system during FY06, a lot of new information and experience have been gained from the low velocity helium recirculation loop development. The lessons and the confirmation of the restrictive helium impurity control learned from the loop development have provided valuable guidance for revisions of the environmental creep testing system design. Several significant design upgrades were made based on the new knowledge and experience to avoid potential construction mistakes and waste of labor. Due to the much more restrictive requirements for helium composition control, the system design has been upgraded to a level that meets standards for vacuum system operation. As a result, the overall system construction cost has been increased accordingly. However, because the designs of each testing chamber and major accessories have not been changed, the cost for future additions of testing chamber to the centralized system at the present location will remain similar. Up to date, the design upgrades are considered mature and the construction will be completed as soon as all the components for the upgrade are received from vendors. 


\section{REFERENCES}

[1] "Environmental Conditions in HTRs and the Selection and Development of Primary Circuit Materials", Gas Cooled Reactors with Emphasis on Advanced Systems, International Atomic Energy Agency, Vol. 1, p. 319-52,1976, L. W. Graham, M. R. Everett, D. Lupton, F. Ridealgh, D. W. Sturge and M. Wagner-Loffler.

[2] "Development of a Physically Based Model for Material Strength and Embrittlement under HTGR Operating Conditions", SBIR Report (Phase I), S. Levy Incorporated, Campbell, California, April 1986, Y. S. Garud and A. K. Miller.

[3] "Corrosion of High Temperature Alloys in the Coolant Helium of a Gas Cooled Reactor", Materials Science Forum 461 - 464, 1165 - 1172 (2004), C. Cabet, A. Monnier, and A. Terlain.

[4] "Initiation of Scoping Tests to Provide Time-Dependent Input for HTDM Constitutive Equation Development”, ORNL-GEN4/LTR-05-006, U. S. Department of Energy Generation IV Nuclear Reactor Program, Office of Nuclear Energy Science and Technology, U. S. Department of Energy, August 30, 2005, W. Ren and R. W. Swindeman.

[5] “Assessment of Existing Alloy 617 Data for Gen IV Materials Handbook”, ORNL/TM2005/510, U. S. Department of Energy Generation IV Nuclear Reactor Program, U. S. Department of Energy, June 30, 2005, W. Ren and R. W. Swindeman.

[6] "Reducing Helium Impurity Depletion in HTGR Materials Testing", Advanced Gas Cooled Reactor Materials Program, Topical Report, General Electric Company, Advanced Nuclear Technology Operation, DOE-ET-34034-107, August 1984, D. H. Baldwin. 
STATUS OF CENTRALIZED ENVIRONMENTAL CREEP TESTING FACILITY PREPARATION AND UPGRADE

\section{Appendix}

Operation Procedures for Environmental Creep Testing System

Presented in Fig. 2 


\section{Operation Procedures}

If not stated, all closable valves are assumed to be initially closed.

\section{GC Calibration}

During long-term tests, calibration can be checked by using calibration gas as sample gas to verify the calibration accuracy.

The steps described here should be verified with the GC manual instructions.

\begin{tabular}{|c|c|c|}
\hline Step & Action & Reason/Purpose/Note \\
\hline 1 & $\begin{array}{l}\text { Ensure valves B, C, F and G are closed. } \\
\text { Open valve A, E, and D, allow bottle C1 gas to } \\
\text { flow for } 1 \text { minute, inject bottle C1 calibration gas } \\
\text { into GC. }\end{array}$ & $\begin{array}{l}\text { To use bottle C1 gas for GC to take } \\
\text { reading for the calibration. Each } \\
\text { bottle should feed GC for } 3 \\
\text { readings. This is the first reading } \\
\text { from bottle C1. }\end{array}$ \\
\hline 2 & Close valve $\mathrm{D}$, allow GC to complete analysis. & $\begin{array}{l}\text { Valve D must be closed to drain the } \\
\text { gas in the tube to get ready for next } \\
\text { reading. }\end{array}$ \\
\hline 3 & $\begin{array}{l}\text { Open valve } \mathrm{D} \text {, inject. } \\
\text { Close valve } \mathrm{D} \text {, allow GC to complete analysis. }\end{array}$ & The second reading from bottle C1 \\
\hline 4 & $\begin{array}{l}\text { Open valve } \mathrm{D} \text {, inject. } \\
\text { Close valve } \mathrm{D} \text {, allow GC to complete analysis. }\end{array}$ & The third reading from bottle C1 \\
\hline 5 & GC will average the 3 readings. & Refer to GC manual for details \\
\hline 6 & $\begin{array}{l}\text { Open valve D. } \\
\text { Close valve A, allow GC to complete analysis and } \\
\text { gas to drain for } 10 \text { seconds. }\end{array}$ & $\begin{array}{l}\text { To drain the gas in lines beyond } \\
\text { valve A to get ready for bottle } C 2 \text {. }\end{array}$ \\
\hline 7 & $\begin{array}{l}\text { Ensure valves } \mathrm{A} \text { and } \mathrm{C} \text { are closed. } \\
\text { Open valve B, allow gas to flow for } 1 \text { minute, } \\
\text { inject calibration gas into GC. } \\
\text { Close valve D. }\end{array}$ & $\begin{array}{l}\text { To use bottle C2 gas for GC } \\
\text { reading. This is the first reading } \\
\text { from bottle C2. }\end{array}$ \\
\hline 8 & Repeat steps $3 \sim 4$ & $\begin{array}{l}\text { The second and third readings from } \\
\text { bottle C2. }\end{array}$ \\
\hline 9 & GC will average the 3 readings. & Same as step 5 \\
\hline 10 & $\begin{array}{l}\text { Open valve } \mathrm{D} \text {. } \\
\text { Close valve B, allow GC to complete analysis and } \\
\text { gas to drain for } 10 \text { seconds. }\end{array}$ & $\begin{array}{l}\text { To drain the gas beyond valve } 2 \text { to } \\
\text { get ready for bottle C3. }\end{array}$ \\
\hline 11 & $\begin{array}{l}\text { Ensure valves A and B are closed. } \\
\text { Open valve C, allow gas to flow for } 1 \text { minute, } \\
\text { inject calibration gas into GC. } \\
\text { Close valve D. }\end{array}$ & $\begin{array}{l}\text { To use bottle C3 gas for GC } \\
\text { reading. This is the first reading } \\
\text { from bottle C3. }\end{array}$ \\
\hline 12 & Repeat step $3 \sim 4$ & $\begin{array}{l}\text { The second and third readings from } \\
\text { bottle C3. }\end{array}$ \\
\hline 13 & GC will average the 3 reading. & \\
\hline
\end{tabular}


STATUS OF CENTRALIZED ENVIRONMENTAL CREEP TESTING FACILITY PREPARATION AND UPGRADE

\begin{tabular}{|c|c|c|}
\hline 14 & $\begin{array}{l}\text { Close valve C. } \\
\text { Open valve D, allow GC to complete analysis and } \\
\text { gas to drain for } 10 \text { seconds. }\end{array}$ & $\begin{array}{l}\text { Drain to empty the calibration gas } \\
\text { line. }\end{array}$ \\
\hline 15 & Close valve D. & $\begin{array}{l}\text { Calibration reading is completed. } \\
\text { Isolate calibration bottles from GC. }\end{array}$ \\
\hline 16 & $\begin{array}{l}\text { Curve fitting the average data points, starting from } \\
\text { linear up to higher polynomial until a good fit is } \\
\text { achieved. }\end{array}$ & $\begin{array}{l}\text { Refer to GC manual for details. The } \\
\text { resulting fit curve will be used for } \\
\text { measurement reading. }\end{array}$ \\
\hline \multicolumn{3}{|c|}{$\begin{array}{l}\text { Calibration complete } \\
\end{array}$} \\
\hline \multicolumn{3}{|c|}{$\begin{array}{l}\text { Procedures for clearing R1 ( or R2, R3) output components } \\
\text { after initial system setup or bottle change }\end{array}$} \\
\hline Step & Action/Status & Reason/Purpose/Note \\
\hline 1 & $\begin{array}{l}\text { Ensure R1 block \& bleed valves are close } \\
\text { Open R1 bottle valve } \\
\text { Set output pressure to } 10 \text { psi } \\
\text { Open R1 bleed valve for } 10 \text { seconds } \\
\text { Close R1 bleed valve } \\
\text { Close R1 bottle valve } \\
\text { Open R1 bleed valve and wait for the bottle gage } \\
\text { pressure to reduce to } 200 \text { psi } \\
\text { Close R1 bleed valve }\end{array}$ & Clear R1 block and bleed valve. \\
\hline 2 & $\begin{array}{l}\text { Repeat the following } 3 \text { times } \\
\text { Open R1 bottle valve } \\
\text { Close R1 bottle valve } \\
\text { Open R1 bleed valve and wait for the bottle gage } \\
\text { pressure to reduce to } 200 \text { psi } \\
\text { Close R1 bleed valve }\end{array}$ & Clear R1 bottle valve and regulator. \\
\hline 3 & $\begin{array}{l}\text { Open R1 bottle valve } \\
\text { Set output pressure to } 2 \text { psi } \\
\text { Open and close R1 bleed valve to release excess } \\
\text { gas and allow the pressure to reach } 2 \text { psi }\end{array}$ & $\begin{array}{l}\text { Set the desired R1 output pressure } \\
\text { for retort use }\end{array}$ \\
\hline \multicolumn{3}{|c|}{ Completion of clearing R1 output components } \\
\hline \multicolumn{3}{|c|}{ Repeat steps $1 \sim 3$ for R2 or R3. The procedure should be done each time a bottle is changed. } \\
\hline \multicolumn{3}{|c|}{ Procedures for clearing the header section lines to all test stands at initial system setup } \\
\hline \multicolumn{3}{|c|}{$\begin{array}{l}\text { The clearing should start from Stand 1. Make sure valve G is connected to the lead line to Stand } \\
1 \text { without any "dead section" due to kinks. }\end{array}$} \\
\hline Step & Action/Status & Reason/Purpose/Note \\
\hline 0 & $\begin{array}{l}\text { Test chamber lines are not connected to valves } 12 \\
\text { and } 13 \text { at each test stand. } \\
\text { All valves are closed }\end{array}$ & Initial system setup status \\
\hline
\end{tabular}


STATUS OF CENTRALIZED ENVIRONMENTAL CREEP TESTING FACILITY PREPARATION AND UPGRADE

\begin{tabular}{|c|c|c|}
\hline 1 & $\begin{array}{l}\text { Open R3 bottle valve } \\
\text { Ensure R3 bleed valve is close } \\
\text { Open R3 block valve } \\
\text { Make sure R3 output pressure is } 2 \text { psi }\end{array}$ & Output R3 gas at desired pressure \\
\hline 2 & Ensure valve E is closed & Isolate GC from the clearing action \\
\hline 3 & $\begin{array}{l}\text { Open valves } F \text { and } G \\
\text { Open valve } 12 \text { of the farthest stand (Stand } 6 \text { in the } \\
\text { drawing) for } 10 \text { seconds } \\
\text { Close valve } 12 \\
\text { Open } 13 \text { for } 10 \text { seconds } \\
\text { Close valve } 13\end{array}$ & $\begin{array}{l}\text { Clear the line from valve } \mathrm{E} \text { to } \\
\text { valves } 12 \text { and } 13 \text { to the stand }\end{array}$ \\
\hline 4 & $\begin{array}{l}\text { Ensure valves } F \text { and } G \text { are open } \\
\text { Open valve } 12 \text { of the second farthest stand (Stand } \\
5 \text { in the drawing) for } 10 \text { seconds } \\
\text { Close valve } 12 \\
\text { Open } 13 \text { for } 10 \text { seconds } \\
\text { Close valve } 13\end{array}$ & $\begin{array}{l}\text { Clear the line from valve } \mathrm{E} \text { to } \\
\text { valves } 12 \text { and } 13 \text { to the Stand }\end{array}$ \\
\hline 5 & $\begin{array}{l}\text { Repeat for each stand that is not being used in } \\
\text { descending order. Then repeat the clearing for } \\
\text { each stand in ascending order. } \\
\text { Ensure valves } 12 \text { and } 13 \text { at each test stand are } \\
\text { closed. } \\
\text { Close valves F and G } \\
\text { Connect test chamber lead lines to valve } 12 \text { and } 13 \text {. }\end{array}$ & $\begin{array}{l}\text { Clear the line from valve } \mathrm{E} \text { to } \\
\text { valves } 12 \text { and } 13 \text { to the rest of the } \\
\text { stands. }\end{array}$ \\
\hline \multicolumn{3}{|c|}{ Completion of clearing the header section lines to all test stands } \\
\hline \multicolumn{3}{|c|}{ Dry up retort } \\
\hline Step & Action/Status & Reason/Purpose/Note \\
\hline 0 & $\begin{array}{l}\text { All valves are closed } \\
\text { Valves W1, W2, W3 and W4 are open to ensure } \\
\text { cooling water flow. }\end{array}$ & $\begin{array}{l}\text { Initial status to begin with. Cooling } \\
\text { water must be on to protect seals } \\
\text { from being overheated. }\end{array}$ \\
\hline 1 & Ensure valve G is closed. & $\begin{array}{l}\text { Isolate the testing chamber from } \\
\text { GC }\end{array}$ \\
\hline 2 & $\begin{array}{l}\text { Ensure R1 output pressure is set for } 2 \text { psi } \\
\text { Open R1 bottle valve } \\
\text { Ensure R1 bleed valve is closed } \\
\text { Open R1 block valve }\end{array}$ & $\begin{array}{l}\text { Output R1 gas to reach valves } 1 \text { and } \\
2 \text { at } 2 \text { psi }\end{array}$ \\
\hline 3 & $\begin{array}{l}\text { Ensure R2 output pressure is set for } 2 \text { psi } \\
\text { Open R2 bottle valve } \\
\text { Ensure R2 bleed valve is closed } \\
\text { Open R2 block valve }\end{array}$ & $\begin{array}{l}\text { Output R2 gas to reach valve } 8 \text { at } 2 \\
\text { psi }\end{array}$ \\
\hline 4 & $\begin{array}{l}\text { Ensure valve 2, 3, } 6 \text { are closed } \\
\text { Open valve 4, and } 5\end{array}$ & $\begin{array}{l}\text { Clear air out of water bubbler using } \\
\text { R1 gas }\end{array}$ \\
\hline
\end{tabular}




\begin{tabular}{|c|c|c|}
\hline & $\begin{array}{l}\text { Slowly open valve } 1 \text { until } 10 \text { bubbles/min flow in } \\
\text { the water bubbler for } 10 \mathrm{~min} \text {. } \\
\text { Close valve } 5 \text {. } \\
\text { Close valve } 1 \text {. } \\
\text { Close valve } 4 \text {. }\end{array}$ & \\
\hline 5 & $\begin{array}{l}\text { Open valve } 2 . \\
\text { Open valve } 5 \text { for } 10 \text { seconds } \\
\text { Close valve } 5 \text {. }\end{array}$ & $\begin{array}{l}\text { Clear air out of valves } 2-5 \text { section } \\
\text { using R1 gas. }\end{array}$ \\
\hline 6 & $\begin{array}{l}\text { Ensure valve } 2 \text { is open } \\
\text { Open valves } 6 \text { and } 10 \text { for } 30 \mathrm{~min}\end{array}$ & $\begin{array}{l}\text { Clear valve } 6 \text { - retort - valve } 10 \text { - } \\
\text { OB2 section using } \mathrm{R} 1 \text { gas. }\end{array}$ \\
\hline 7 & $\begin{array}{l}\text { Open valve } 12,13 \text { for } 5 \text { min } \\
\text { Close valve } 2,6,10,12,13\end{array}$ & $\begin{array}{l}\text { Clear valves } 6-13-12-10 \text { section } \\
\text { using R1 gas. }\end{array}$ \\
\hline 8 & $\begin{array}{l}\text { Ensure valve 2, 6, G, } 12 \text { and } 13 \text { are closed. } \\
\text { Open valve } 7 \\
\text { Adjust R2 micro metering valve for } 10-100 \\
\text { ml/min with flow meter M1 } \\
\text { Open valves } 9 \text { and 11, ensure there is flow through } \\
\text { flow meters M2 and M3 } \\
\text { Watch the vacuum pressure gage, if pressure } \\
\text { exceeds } 2 \text { psi, open valve 10, otherwise keep valve } \\
10 \text { closed. } \\
\text { Allow follow for } 1 \text { min through M2 and M3 (may } \\
\text { need to develop procedures for the moisture } \\
\text { detector) } \\
\text { Close valves } 9 \text { and } 11 \text {. } \\
\text { Close valve } 7 .\end{array}$ & $\begin{array}{l}\text { Clear valve } 9 \text { - M2 - MD1 - OB1 - } \\
\text { vent section, and valve } 11-\text { M3 - } \\
\text { MD3 - vent section using R2 gas. } \\
\text { This also clears bottle R2 feed lines. }\end{array}$ \\
\hline 9 & $\begin{array}{l}\text { Make sure valves } 1,2,3,4,5,6,7,9,10,11,12 \text {, } \\
13 \text {, and bottle } \mathrm{R} 1 \text { bleed valve are closed. } \\
\text { Connect vacuum machine to vacuum valve. } \\
\text { Open vacuum valve. } \\
\text { Turn on vacuum machine. } \\
\text { Evacuate the system at room temperature to } 1 \times 10^{-} \\
6 \text { torr. }\end{array}$ & $\begin{array}{l}\text { Empty the retort and the line from } \\
\text { valves } 6,7,9,10,13,11 \text {, and } 12 \text {. }\end{array}$ \\
\hline 10 & $\begin{array}{l}\text { Heat furnace under vacuum to } 200^{\circ} \mathrm{C} \text { at } 25^{\circ} \mathrm{C} / \text { hour. } \\
\text { Remain at } 200^{\circ} \mathrm{C} \text { for } 24 \text { hours, or until getting back } \\
\text { to the vacuum before heating up }\left(1 \times 10^{-6} \text { torr here }\right) \\
\text { Keep the vacuum pump running. }\end{array}$ & $\begin{array}{l}\text { To remove moisture from the } \\
\text { system. } \\
\text { Manufacturer instructs ceramic } \\
\text { retort heating rate }<100^{\circ} \mathrm{C} / \mathrm{h} \text {. } \\
25^{\circ} \mathrm{C} / \mathrm{h} \text { prevents loosing vacuum to } \\
\text { fast due to fast out-gassing. }\end{array}$ \\
\hline 11 & $\begin{array}{l}\text { Cool furnace at } 80^{\circ} \mathrm{C} / \text { hour to room temperature } \\
\text { while keeping vacuum pump running. }\end{array}$ & $\begin{array}{l}\text { Manufacturer instructs ceramic } \\
\text { retort cooling rate }<100^{\circ} \mathrm{C} / \mathrm{h} \text {. }\end{array}$ \\
\hline 12 & Turn off W1, W2, W3 and W4. & Stop cooling water flow \\
\hline \multicolumn{3}{|c|}{ Completion of retort drying } \\
\hline
\end{tabular}


STATUS OF CENTRALIZED ENVIRONMENTAL CREEP TESTING FACILITY PREPARATION AND UPGRADE

\begin{tabular}{|c|c|c|}
\hline \multicolumn{3}{|c|}{ First retort leakage/degass check } \\
\hline 1 & $\begin{array}{l}\text { Ensure valves } 1,4,5,7,9,10,11,12 \text {, and } 13 \text { are } \\
\text { closed. } \\
\text { Close vacuum valve. } \\
\text { Ensure bottle R1 block valve is open and output } \\
\text { pressure is set for } 2 \text { psig } \\
\text { Open valves } 2,6 \text {. }\end{array}$ & $\begin{array}{l}\text { Back fill the retort with pure } \mathrm{He} \\
\text { from bottle R1 slowly to } 2 \text { psig max } \\
\text { (ATS specified value, exceeding } \\
\text { this value will damage the retort.) }\end{array}$ \\
\hline 2 & $\begin{array}{l}\text { Turn off turbo pump. After } 1 \text { minute, slightly open } \\
\text { and close turbo pump bleed valve. Allow turbo } \\
\text { pump to come to a stop. Turn off mechanical } \\
\text { pump. }\end{array}$ & $\begin{array}{l}\text { Prevent mechanical pump oil back } \\
\text { streaming into turbo pump. } \\
\text { (The necessity of this depends on } \\
\text { the pump eventually employed for } \\
\text { testing.) }\end{array}$ \\
\hline 3 & $\begin{array}{l}\text { Open valve } 10 \text { after vacuum-pressure gage reaches } \\
1 \text { psig (This is slightly above } 1 \text { absolute atm to } \\
\text { prevent oil back stream) } \\
\text { Keep flow for } 30 \text { minutes. }\end{array}$ & Prepare retort for the check \\
\hline 4 & $\begin{array}{l}\text { During the flowing time, open valves } 12, \mathrm{E} \text { and } \mathrm{G} \text {, } \\
\text { close valve } 10 \text {, flow for } 60 \text { seconds or to be } \\
\text { determined time depending on how far the retort is } \\
\text { from GC to clear the line, then inject. } \\
\text { Close valves } G, 12 \text {. }\end{array}$ & $\begin{array}{l}\text { Retort output gas analysis on pure } \\
\text { He from bottle R1, look for N peak } \\
\text { etc to determine how good the } \\
\text { system is, is there any leakage? }\end{array}$ \\
\hline 5 & $\begin{array}{l}\text { Open valves } 13 \text { and } G \text {, flow for } 60 \text { second or to be } \\
\text { determined time depending on how far the retort is } \\
\text { from GC to clear the line to clear the line, then } \\
\text { inject. } \\
\text { Close valve } G, 13 \text {. }\end{array}$ & $\begin{array}{l}\text { Retort input gas analysis on pure } \\
\text { He from bottle R1, look for N peak } \\
\text { etc to determine how good the } \\
\text { system is. }\end{array}$ \\
\hline 6 & $\begin{array}{l}\text { Compare the input and output analysis and } \\
\text { determine the cause, if any, for contamination } \\
\text { either from the system or from the input gas. }\end{array}$ & \\
\hline 7 & $\begin{array}{l}\text { Close valves 2, } 6 \text { and } 10 \text { (If } 10 \text { is not close, oil will } \\
\text { back flow into the empty reservoir. If this } \\
\text { happens, transfer the oil from the reservoir back } \\
\text { into the bubbler.). Evacuate system at room } \\
\text { temperature to } 1 \times 10^{-6} \text { torr. }\end{array}$ & $\begin{array}{l}\text { Stop feeding the retort with bottle } \\
\text { R1 gas. }\end{array}$ \\
\hline \multicolumn{3}{|c|}{ First retort leakage check complete } \\
\hline \multicolumn{3}{|c|}{ Second retort leakage check } \\
\hline 8 & $\begin{array}{l}\text { Ensure valves } 1,4,5,7,9,10,11,12 \text { and } 13 \text { are } \\
\text { closed. } \\
\text { Ensure vacuum valve is closed. } \\
\text { Ensure bottle R1 block valve is open and output } \\
\text { pressure is set for } 2 \text { psig. } \\
\text { Open valves 2, } 6 \text {. }\end{array}$ & $\begin{array}{l}\text { Back fill the retort with pure He } \\
\text { from bottle R1 slowly to } 2 \text { psig max } \\
\text { (ATS specified value, exceeding } \\
\text { this value will damage the retort.) }\end{array}$ \\
\hline
\end{tabular}


STATUS OF CENTRALIZED ENVIRONMENTAL CREEP TESTING FACILITY PREPARATION AND UPGRADE

\begin{tabular}{|c|c|c|}
\hline 9 & $\begin{array}{l}\text { Open valve } 10 \text { after vacuum-pressure gage reaches } \\
1 \text { psig (slightly above } 1 \text { absolute atm to prevent oil } \\
\text { back stream) } \\
\text { Keep flow for } 30 \text { minutes. }\end{array}$ & Prepare retort for the check \\
\hline 10 & $\begin{array}{l}\text { During the flowing time, open valves } 12 \text { and } G \text {, } \\
\text { flow for } 60 \text { second to clear the line, then inject. } \\
\text { Close valve } G, 12 \text {. }\end{array}$ & $\begin{array}{l}\text { Retort output gas analysis on pure } \\
\text { He from bottle R1, look for N peak } \\
\text { etc to determine how good the } \\
\text { system is, is there any leakage? }\end{array}$ \\
\hline 11 & $\begin{array}{l}\text { Open valve } G, 13 \text {, flow for } 60 \text { second to clear the } \\
\text { line, then inject. } \\
\text { Close valve } G, 13 \text {. }\end{array}$ & $\begin{array}{l}\text { Retort input gas analysis on pure } \\
\text { He from bottle R1, look for N peak } \\
\text { etc to determine how good the } \\
\text { system is. }\end{array}$ \\
\hline 12 & $\begin{array}{l}\text { Compare the input and output analysis and } \\
\text { determine the cause, if any, for contamination } \\
\text { either from the system or from the input gas. }\end{array}$ & \\
\hline 13 & $\begin{array}{l}\text { Close valve } 6 \text { and } 10,12,13 \text {. Evacuate system at } \\
\text { room temperature to } 1 \times 10^{-6} \text { torr. } \\
\text { Compare with step } 6 \text {. }\end{array}$ & Clear the retort of bottle R1 gas. \\
\hline \multicolumn{3}{|c|}{ Second retort leakage check complete } \\
\hline & Check on impure He line & Reason/Purpose/Note \\
\hline 14 & $\begin{array}{l}\text { Ensure valves } 1,2,4,6,9,10,11,12 \text {, and } 13 \text { are } \\
\text { closed. } \\
\text { Close the vacuum valve. } \\
\text { Ensure bottle R2 bleed valve is closed. } \\
\text { Ensure bottle R2 output pressure gage is set for } 2 \\
\text { psig. } \\
\text { Open valve } 7 \text {, micro metering valve } 8 \text {, and bottle } \\
\text { R2 block valve. } \\
\text { Open valve } 10 \text { after vacuum-pressure gage reaches } \\
1 \text { psig (slightly above } 1 \text { absolute atm to prevent oil } \\
\text { back stream) } \\
\text { Keep flow for } 30 \text { min. }\end{array}$ & $\begin{array}{l}\text { Back fill the retort with impure He } \\
\text { from bottle R2 slowly to } 2 \text { psig max } \\
\text { (ATS specified value, exceeding } \\
\text { this value will damage the retort.) }\end{array}$ \\
\hline 15 & $\begin{array}{l}\text { During the flowing time, open valves E, 12, and G, } \\
\text { flow for } 60 \text { second to clear the line, then inject. } \\
\text { Close valves } G, 12 \text {. }\end{array}$ & $\begin{array}{l}\text { Retort output gas analysis on } \\
\text { impure He from bottle R2, look for } \\
\mathrm{N} \text { peak etc to determine how good } \\
\text { the system is, is there any leakage? } \\
\text { Compare to calibration gases and } \\
\text { specimens on impure He }\end{array}$ \\
\hline 16 & Open valve $\mathrm{G}, 13$, flow for 60 second to clear the & Retort input gas analysis on impure \\
\hline
\end{tabular}


STATUS OF CENTRALIZED ENVIRONMENTAL

CREEP TESTING FACILITY PREPARATION AND UPGRADE

\begin{tabular}{|c|c|c|}
\hline & $\begin{array}{l}\text { line, then inject. } \\
\text { Close valve G, } 13 .\end{array}$ & $\begin{array}{l}\text { He from bottle R2, look for } \mathrm{N} \text { peak } \\
\text { etc to determine how good the } \\
\text { system is. } \\
\text { Compare to calibration gases and } \\
\text { specimens on impure He }\end{array}$ \\
\hline \multirow[t]{2}{*}{17} & $\begin{array}{l}\text { Compare the input and output analysis and } \\
\text { determine the cause, if any, for contamination } \\
\text { either from the system or from the input gas. }\end{array}$ & \\
\hline & Impure He line check complete & \\
\hline & Heat up for creep testing & Reason/Purpose/Note \\
\hline 18 & Heat up system at $80^{\circ} \mathrm{C} /$ hour & To avoid ceramic retort cracking \\
\hline \multirow[t]{2}{*}{19} & $\begin{array}{l}\text { Repeat “Check on impure He line” steps (steps } 14 \\
\sim 17 \text { ) once/hour, or 3 4 times, during heating up }\end{array}$ & $\begin{array}{l}\text { Compare input and output gas } \\
\text { chemistries. Increase flow rate if } \\
\text { depletion of species from input gas } \\
\text { is found. }\end{array}$ \\
\hline & Testing heating up complete & \\
\hline & $\begin{array}{l}\text { Start creep testing } \\
\text { (Need to develop details, especially about the } \\
\text { bellow force calibration) }\end{array}$ & Reason/Purpose/Note \\
\hline 20 & $\begin{array}{l}\text { Load the specimen with prescribed creep stress } \\
\text { after the temperature is stabilized and temperature } \\
\text { gradient is achieved. }\end{array}$ & \\
\hline 21 & $\begin{array}{l}\text { Measure output gas as frequently as needed to } \\
\text { ensure the prescribed gas chemistry by comparing } \\
\text { it with input gas chemistry. }\end{array}$ & $\begin{array}{l}\text { Need to increase input flow rate if } \\
\text { depletion is more than prescribed } \\
\text { value. }\end{array}$ \\
\hline 22 & $\begin{array}{l}\text { Reduce output gas analysis to convenient } \\
\text { frequency (once/day, once/week?) }\end{array}$ & \\
\hline
\end{tabular}




\section{Distribution}

1. T. D. Burchell

2. W. R. Corwin

3. S. R. Greene

4. D. T. Ingersoll

5. Y. Katoh

6. J. W. Klett

7. E. Lara-Curzio

8. L. K. Mansur

9. T. E. McGreevy

10. R. K. Nanstad
11. R. A. Raschke

12. W. Ren

13. P. L. Rittenhouse

14. A. F. Rowcliff

15. L. L. Snead

16. R. G. Stoller

17. R. W. Swindeman

18. P. F. Tortorelli

19. D. F. Wilson

20. S. J. Zinkle

21. Cathy Barnard, Idaho National Engineering and Environmental Laboratory, P.O. Box 1625, Idaho Falls, Idaho 83415-3750

22. Trevor Cook, NE-20/Germantown Building, Office of Advanced Nuclear Research, U.S. Department of Energy, 1000 Independence Avenue, S.W., Washington, DC 20585-1290

23. Susan Lesica, NE-20/Germantown Building, Office of Advanced Nuclear Research, U.S. Department of Energy, 1000 Independence Avenue, S.W., Washington, DC 20585-1290

24. Thomas J. O’Conner, NE-20/Germantown Building, Office of Advanced Nuclear Research, U.S. Department of Energy, 1000 Independence Avenue, S.W., Washington, DC 20585-1290

25. Rafael Soto, Idaho National Engineering and Environmental Laboratory, P.O. Box 1625, Idaho Falls, Idaho 83415-3750

26. Robert Versluis, NE-20/Germantown Building, Office of Advanced Nuclear Research, U.S. Department of Energy, 1000 Independence Avenue, S.W., Washington, DC 205851290

27. Kevan Weaver, Idaho National Engineering and Environmental Laboratory, P.O. Box 1625, Idaho Falls, Idaho 83415-3750

28. R. Battiste, ORNL 